\title{
TOLUENE MEDIATED OXIDATIVE STRESS AND GRANULO-MONOCYTOPOIESIS
}

\author{
BOŽIĆ TATJANA*, STEVANOVIĆ JELKA*, KOVAČEVIĆ MILICA*, JOVIĆ S*, LUKIĆ SANJA*, \\ PETAKOV MARIJANA**, BOROZAN SUNČICA*, MIJAČEVIĆ ZORA*, KNEŽEVIĆ MILIJANA* and \\ BULAJIĆ SNEŽANA*
}

* Faculty of Veterinary Medicine, University of Belgrade, Serbia and Montenegro, ** Institute for Medical Research, Belgrade, Serbia and Montenegro

\section{(Received 1. March, 2003)}

The influence of toluene exposure on some biochemical and hematological parameters was investigated in adult female Wistar rats. The animals were subjected to intraperitoneal administration of toluene diluted in propylene glycol and the diluent alone for 3, 7 and 11 consecutive days at the same time intervals. The effects of toluene and propylene glycol were evaluated biochemically by determining the plasma concentrations of total proteins, albumin and ceruloplasmin (Cp) together with erythrocyte malondialdehyde (MDA), and hematological indices from peripheral blood and bone marrow. The biochemical acute phase response was manifested by an elevated Cp concentration in all experimental animals. The markedly enhanced MDA concentration and statistically significant decrease in albumin level in toluene treated rats, indicated damage, to blood vessel endothelia. Alterations of leukocytes of peripheral blood and bone marrow (BM) granulocytic-monocytic progenitor cells were typical of an inflammatory response, with stimulation of granulo-monocytopoiesis. Therefore, it can be assumed that both toluene and propylene glycol mediated sterile peritonitis and oxidative stress injury, with changes intensified by toluene action.

Key words: rat, ceruloplasmin, hematological indices, malondialdehyde, propylene glycol, toluene

\section{INTRODUCTION}

Individuals are exposed to oxidative stress even before birth. Sources of oxidative stress are ubiquitous and include, in particular, the oxidative burst of neutrophils, ischemia-reperfusion events, cytochrome P450 action, prostaglandins, xenobiotics, aerobic or long duration exercise, emotional stress etc. (Chen et al., 2003; Cichetti and Argentin, 2003; Ajmani et al., 2003; Tauler et al., 2002). Oxidative stress can also ensue from environmental causes, such as UV radiation, pollution (Grella et al., 2002), cigarette smoke (Kim et al., 2003), as well as from some medical interventions, like laparoscopy and open surgery (Bentes De Souza et al., 2003). 
Toluene is a ubiquitous chemical commonly used for its solvent properties in industry and manufacturing. For that reason there is a potential for both occupational and nonoccupational exposure to it. The influence of toluene has been examined in many studies, with contradictory results and discrepancies concerning the interpretation of adverse effects (Wang et al., 1996; Nedelcheva, 1996; Neghab and Stacey, 1997; Pedersen and Rasmussen, 1982). It is known that toluene and its metabolites, benzyl alcohol and hippuric acid (Smith-Kielland et al., 1993; Backes et al., 1993; Paguotto et al., 1967), are capable of inducing oxidative stress generating reactive oxygen (ROS) and nitrogen species (RNS) in the liver, central nervous system, lung and kidney, with consequent tissue damage (Hauffman et al., 1997; Tamizhselvi et al., 1995; Mattia et al., 1993a; Mattia et al., 1993b; Myhre et al., 2001).

We focused our investigation on the acute effects of toluene in vivo, with respect to its ROS enhancing potential, and influence on some plasma proteins and cells in bone marrow and blood, including its impact on granulocyte-monocyte progenitors (CFU-GM).

\section{MATERIAL AND METHODS}

\section{Animals}

Adult female Wistar rats, weighing between $250-300 \mathrm{~g}, 2.5-3$ months old (Institute for Medical Research, Belgrade) were kept in cages with free access to food pellets and water. All experiments were performed in accordance to the principles and guidelines of the Canadian Council on Animal Care /CCAC/. Rats were anaesthetized by intramuscular application of $0.5 \mathrm{ml}$ of a mixture of ketamine, ketalar and formidal in doses of $75 \mathrm{mg} / \mathrm{kg} \mathrm{b.m.,} 15 \mathrm{mg} / \mathrm{kg} \mathrm{b.m.} \mathrm{and} 0.75 \mathrm{mg} / \mathrm{kg}$ b.m., respectively.

\section{Experimental design}

The animals were divided into three groups: a negative control group of eight untreated rats (group C); a control group of rats, which received propylene glycol $(0.3 \mathrm{ml} / 200 \mathrm{~g}$ b.m.; $\mathrm{n}=24)$ (group $P G)$ and group $T$ containing rats which received toluene $(0.7 \mu \mathrm{m})$ diluted in propylene glycol $(0.3 \mathrm{ml} / 200 \mathrm{~g}$ b.m.; $n=24)$. Groups PG and T were treated intraperitoneally daily for 3, 7 or 11 days, and were sacrificed on the respective following day at definite time intervals.

Blood was obtained directly by heart puncture. EDTE plasma was separated from whole blood after centrifugation at $3000 \mathrm{rpm}$, and immediately stored at $-20^{\circ} \mathrm{C}$ until the tests were done.

\section{Biochemical measurements}

The oxidase activity of $\mathrm{Cp}$ in plasma was obtained using a colorimetric enzyme assay (Sunderman et al., 1970) using a spectrophotometer (Spekord M40, Karl Zeiss, Jena) at $530 \mathrm{~nm}$.

Total protein and albumin concentrations were estimated by the colorimetric albumin-BCG (brom-cresol-green) method, at $628 \mathrm{~nm}\left(25^{\circ} \mathrm{C}\right.$, pH 4.2; Basic Spec- 
trophotometric Biochemical Analyser, Secomam, France). Erythrocyte MDA concentrations were determined using a colorimetric procedure (Uchiyama et al., 1978) at $535 \mathrm{~nm}$ on a spectrophotometer (Spekord M40, Karl Zeiss, Jena). Haemoglobin concentration was detected colorimetrically (Tentori et al., 1981), at 540 $\mathrm{nm}$ on a spectrophotometer (Spekord M40, Karl Zeiss, Jena).

\section{Determination of peripheral blood parameters}

Total leukocytes were enumerated manually using a haemocytometer after suspension in Turk solution. Blood smears were stained with May-GrunwaldGiemsa, and differential cell counts were made (at least 100 cells/counted sample).

Determination of granulocyte-macrophage progenitor cells - CFU-GM

Bone marrow cells were flushed out of the femurs and suspended in Dulbecco's Modification of Eagle's Medium (DMEM, GibcoBRL, Life Technologies, Paisley, Scotland). Bone marrow nucleated cells were counted using the same procedure applied for total peripheral blood leukocytes.

The viability of cells was determined using the trypan-blue exclusion test.

Colony forming assay for granulocyte-macrophage progenitor cells CFU-GM

Clonal assays were performed essentially as previously described (Stojanović et al., 1988). Cells recovered directly from donor animals were plated in 35 $\mathrm{mm}$ Petri dishes in a culture medium containing $0.9 \%$ methylcellulose, $20 \%$ of fetal calf serum (Methocult GF M 3434 Stem Cell Technologies, Vancouver, Canada) and incubated at $37^{\circ} \mathrm{C}$ in a humidified atmosphere with $5 \% \mathrm{CO}_{2}$ in air (Haereus incubator, type I). CFU-GM derived colonies were counted on day 7 , under an inverted microscope (magnification $\times 50$ ) as groups with more than 50 cells.

\section{Statistical analyses}

The data are expressed as arithmetic mean \pm standard error. One way analysis of variance (ANOVA) was applied. When the results of ANOVA were significant, Student's t-test (two-sample assuming equal variance) was performed to determine the level of significance and probability.

\section{RESULTS}

\section{Biochemical parameters}

In the course of the experiment, total protein concentration remained in the physiological range (data not shown), while albumin levels were significantly depressed $(p<0.001)$ in plasma from all treated groups compared to the control animals (Fig 1). 


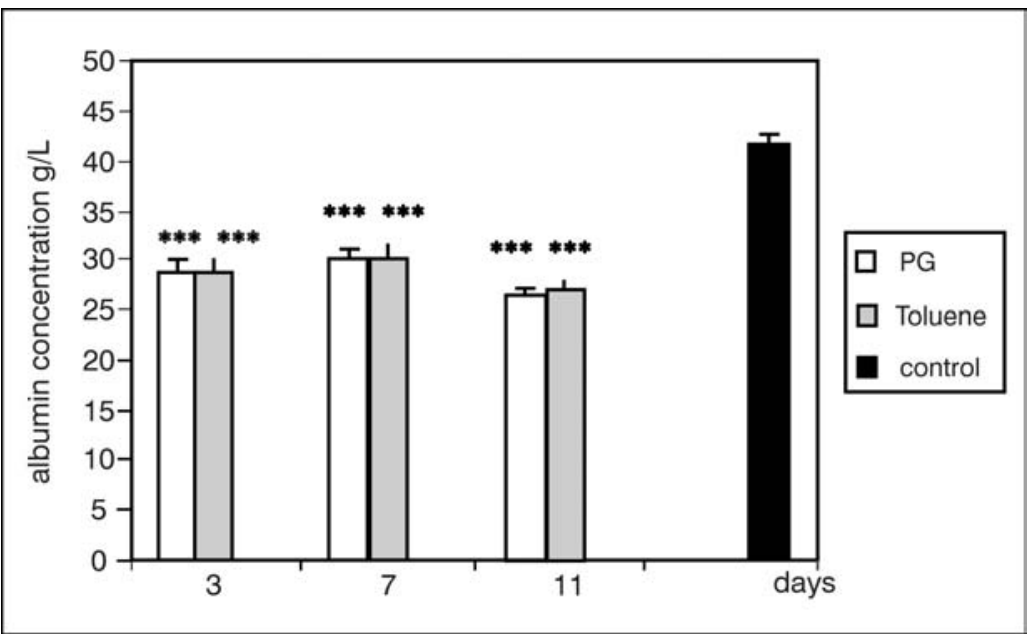

Figure 1. Effect of toluene application on plasma albumin concentration in rats. Values are presented as mean \pm SE for 8 animals. $(* * *) p<0.001$ vs control

Mean ceruloplasmin concentration showed a statistically significant increase after 7 days of application in group PG $(p<0.001)$ and group $T(p<0.05)$, compared to that in the untreated rats (Figure 2). Changes in erythrocyte MDA were detected only after toluene treatment, reaching a 5-fold increase after 11 days of treatment, in comparison to the control and PG treated rats (Figure 3).

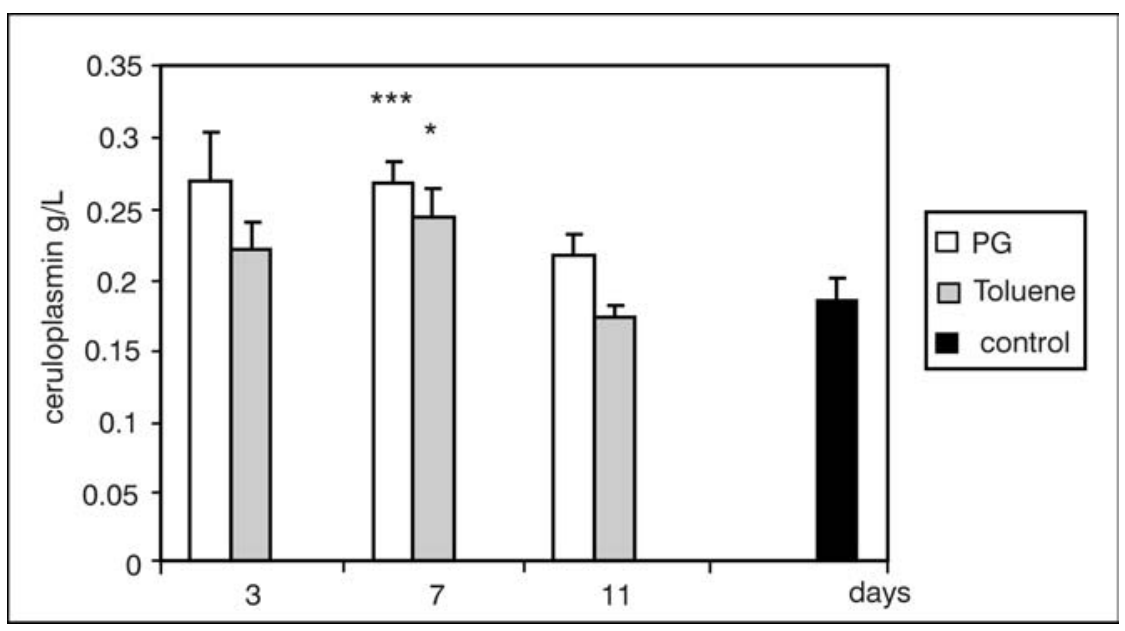

Figure 2. Effect of toluene application on plasma $\mathrm{Cp}$ concentration in rats. Values are presented as mean \pm SE for 8 animals. $\left({ }^{* * *}\right) p<0.001$ and $\left(^{*}\right) p<0.05$ vs control 
Acta Veterinaria (Beograd), Vol. 53. No. 4, 201-210, 2003.

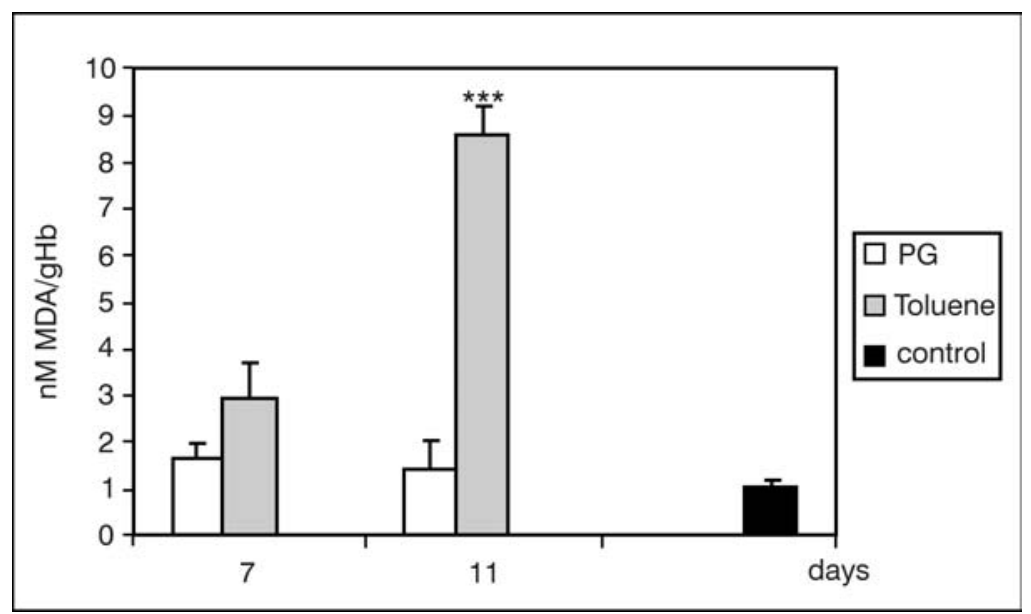

Figure 3. Effect of toluene application on erythrocyte MDA concentration in rats. Values are presented as mean \pm SE for 8 animals.

$\left.{ }^{* * *}\right) p<0.001$ vs control

\section{Blood and marrow cellular reaction.}

The peripheral blood parameters in the control group were in the physiological range for this species (data not shown).

Table 1. Effect of toluene application on rat white blood cells number.

\begin{tabular}{|c|c|c|c|c|c|c|c|}
\hline \multirow{2}{*}{$\begin{array}{l}\text { Day of } \\
\text { application }\end{array}$} & \multicolumn{2}{|c|}{$3^{\text {rd }}$} & \multicolumn{2}{|c|}{$7^{\text {th }}$} & \multicolumn{2}{|c|}{$11^{\text {th }}$} & \multirow{2}{*}{ Control } \\
\hline & Toluene & $P G$ & Toluene & $P G$ & Toluene & $P G$ & \\
\hline $\begin{array}{l}\text { Total } \\
\text { leukocytes } \\
\text { (x 109/L) }\end{array}$ & $15.8 \pm 1.8$ & $8.6 \pm 0.9 * \star \star$ & $23.3 \pm 3.0$ & $18.0 \pm 2.0$ & $19.9 \pm 2.3$ & $17.7 \pm 1.9$ & $16.9 \pm 1.1$ \\
\hline $\begin{array}{l}\text { Lymphocytes } \\
\text { (× 109/L) }\end{array}$ & $11.6 \pm 1.4$ & $6.3 \pm 0.6^{\star \star \star}$ & $15.5 \pm 2.1$ & $12.6 \pm 1.4$ & $13.8 \pm 1.9$ & $13.0 \pm 0.8$ & $14.4 \pm 1.1$ \\
\hline $\begin{array}{l}\text { Neutrophils } \\
\text { (x 109/L) }\end{array}$ & $3.2 \pm 0.5^{\star *}$ & $1.6 \pm 0.2$ & $5.7 \pm 1.2^{\star *}$ & $4.0 \pm 0.8^{* *}$ & $4.6 \pm 0.9^{\star \star}$ & $3.1 \pm 0.6^{*}$ & $1.6 \pm 0.1$ \\
\hline $\begin{array}{l}\text { Monocytes } \\
\text { (x 109/L) }\end{array}$ & $0.8 \pm 0.1$ & $0.5 \pm 0.2$ & $2.1 \pm 0.3^{* * *}$ & $1.3 \pm 0.1^{\star \star}$ & $1.4 \pm 0.3$ & $1.2 \pm 0.5$ & $0.8 \pm 0.09$ \\
\hline
\end{tabular}

Values are presented as mean \pm SE for 8 animals.

$\left(^{* * *}\right) p<0.001,\left({ }^{* *}\right) p<0.01$ and $\left(^{*}\right) p<0.05$ vs control.

PG treatment induced a transient leukopaenia (Table 1) after 3 days, $p<0.001$ (mostly by a decrease in lymphocyte number), without visible changes 
of total BM cells (Figure 4A) and CFU-GM populations (Fig 4B). This onset of leukopoenia was compensated after 7 days treatment (Table 1), but with an increase in the relative proportion of peripheral blood neutrophils $(4.049 \pm 0.750, \mathrm{n}=8)$ and monocytes $(1.309 \pm 0.121 ; n=8)$. This compensation seems to be the result of a

A

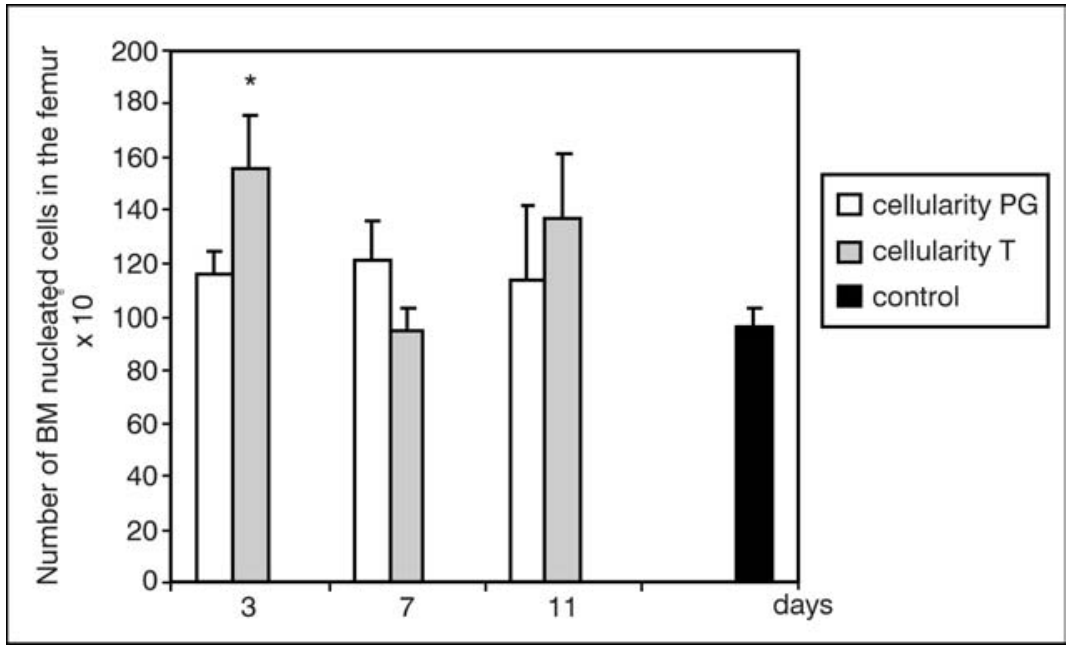

Values are presented as mean \pm SE for 8 animals.

(*) $p<0.05$ vs control

B

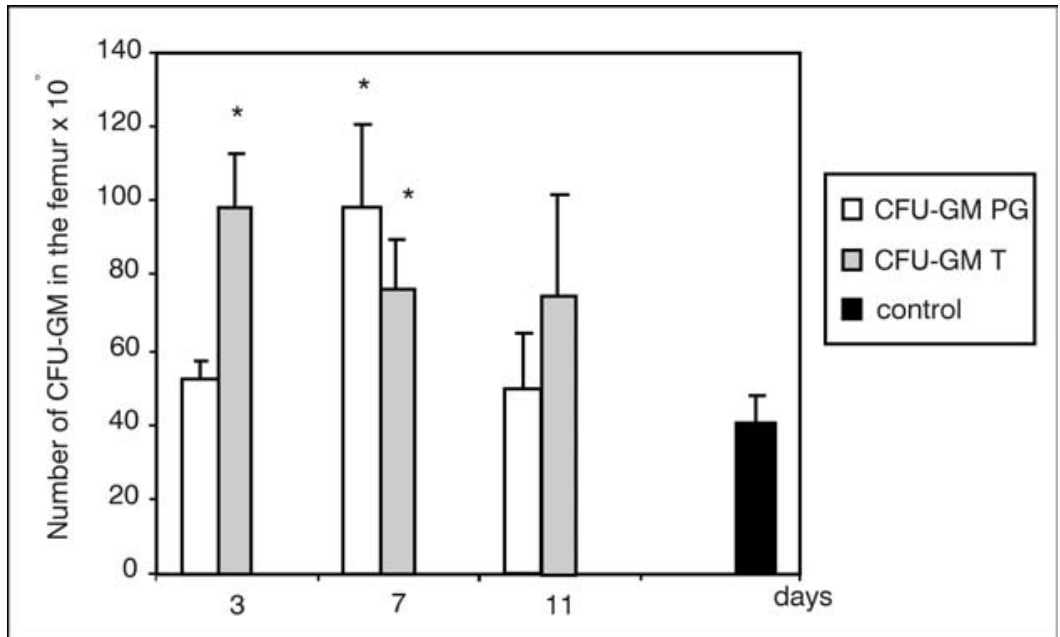

Values are presented as mean \pm SE of 8 animals.

$\left.{ }^{*}\right) p<0.05$ vs control

Figure 4. Effect of toluene application on rat bone marrow cellularity $(A)$ and on the number of CFU-GM (B). 
Acta Veterinaria (Beograd), Vol. 53. No. 4, 201-210, 2003.

progenitor cell compartment activation, since an increased number of CFU-GM per femur was detected after 7 days treatment (Fig 4B), although the increase in total number of bone marrow cells did not reach a statistically significant level (Fig 4A).

In contrast, toluene prevented this leukopenic effect of PG treatment (Table1). Furthermore, it provoked a rapid neutrophil (since day 3) and monocyte (day 7) increase, without affecting the total lymphocyte number (Table 1). These effects, observed in peripheral blood, were probably due to an effective stimulation of bone marrow GM progenitors, that probably occured early (at day $3 \mathrm{CFU}$ GM number doubled - Fig 4B) and the total number of BM cells increased significantly (Fig 4A). Furthermore, the increased number of BM CFU-GM persisted for at least 7 days (Fig 4B).

\section{DISCUSSION}

Malondialdehyde (MDA) is one of the end-products of the peroxidation of membrane lipids caused by ROS formation (Patockova et al., 2003), especially by the superoxide ion. It is currently considered to be a basic marker of oxidative stress. The marked rise in red blood cell MDA concentration after toluene treatment observed here indicates uncured cellular damage induced by ROS induction, as previously seen by Myhre et al., (2001), Mattia et al., (1993a) and Mattia et al. (1993b). The decline in albumin concentration could be ascribed to increased endothelial barrier permeability (Tamizhselvi et al., 1995). However, this phenomenon was also detected in the absence of toluene treatment and under the condition of low erythrocyte MDA levels. Therefore, possible vessel damage was not provoked solely by the influence of $\mathrm{O}_{2}$ radicals and it could rather be the result of an inflammatory reaction. Moszczynski and Coworkers (1983a; 1983b; 1980) showed reduction of intact lymphocyte lysosomes and intensified metabolic activity of peripheral blood neutrophils, with diminished peroxidase activity.

Accelerated synthesis of ceruloplasmin with a significant rise in mean concentration in group $\mathrm{T}$ rats is associated with the liver and possibly to activated monocytes of peripheral blood (Mazumder et al., 1997; Gaitskhoki et al., 1990). As the increased $\mathrm{Cp}$ level was accompanied by a low erythrocyte MDA concentration, we may infer a possible protective role against oxidizing agents (Reyes and Holmgren, 1991; Yang et al., 1993; Saenko et al., 1990). Further investigations should be made to elucidate this question.

At the very start of the acute phase response the body has an increased need for mature, functional cells of granulocyte-monocyte origin, at first satisfied by mobilizing mature cells from the marginal pools and later from the reserve compartment of the bone marrow. This is rapidly compensated by de novo production. This typical response of the granulo-monocytic lineage, best analyzed by a rat model of sterile peritonitis (Jovčić et al., 1993; Milenković et al., 1993), was evident in the toluene-treated animals. Since this in vivo cellular response occurs in the context of an inflammatory reaction, the cellular changes (stimulation of the progenitor compartment) may be explained by reactive induction of stimulatory factors and cytokine production (Stojanović et al., 1988; Milenković, 1993). This 
could be amplified by oxidative stress, which also induces the production of tumour necrosis factor (TNF), interleukin (IL)-1 and IL-6 (Vassilakopoulos et al., 2003). As MDA increases, the oxidative stress most probably occurs after toluene administration. This could be the major (albeit not exclusive) explanation for our results showing acute stimulation of medullar granulo-monocytopoiesis by toluene treatment.

In conclusion, our results confirm that toluene induces oxidative stress. Furthermore, the changes induced by ROS formation extend to bone marrow progenitors, a phenomenon never described before. Although the concentrations of pro-inflammatory cytokines especially IL-1, IL-3, II-6 and TNF were not determined in this work, their induction by toluene treatment is very probable, which might explain the stimulation of BM CFU-GM found here.

\title{
Acknowledgements
}

This study was financially supported by grant number 1518 of the Ministry of Science and Technology, of Serbia.

\author{
Address for correspondence: \\ Dr Tatjana Božić \\ Department of Pathophysiology, \\ Faculty of Veterinary Medicine, \\ University of Belgrade \\ Bul. JA 18, 11000 Beograd, \\ Serbia and Montenegro \\ E-mail: tbozic@vet.bg.ac.yu
}

\section{REFERENCES}

1. Ajmani RS, Fleg JL, Demehin AA, Wright JG, O Connor F, Heim JM et al, 2003, Oxidative stress and hemorheological changes induced by acute treadmill exercise, Clin Hemorheol Microcir, 28, 29-40.

2. Backes WL, Sequeira DJ, Cawley GF, Eyer CS, 1993, Relationship between hydrocarbon structure and induction of P450 : effects on protein levels and enzyme activities, Xenobiotica, 23, 135366.

3. Bentes De Souza AM, Rogers MS, Wang CC, Yuen PM, 2003, Comparison of peritoneal oxidative stress during laparoscopy and laprotomy. J Am Assoc Gynecol Laparosc, 10, 65-74.

4. Chen CY, Wang YF, Lin YH, Yen SF, 2003, Nickel induced oxidative stress and effect of antioxidants in human lymphocytes, Arch Toxicol, 77, 123-30.

5. Cicchetti R, Argentin $G, 2003$, The role of oxidative stress in the in vitro induction of micronuclei by pesticides in mouse lung fibroblasts, Mutagenesis, 18, 127-33.

6. Gaitskhoki VS, Voronina OV, Denezhkina VV, Pliss MG, Puchkova LV, Shvartsman AL, Neifakh SA, 1990, Expression of ceruloplasmin gene in various organs of the rat, Biokhimiia, 55, 927-37.

7. Grella E, Paciocco G, Caterino U, Mayyarella G, 2002, Respiratory function and atmospheric pollution. Monaldi Arch Chest Dis, 57, 196-9.

8. Huffman LJ, Judy DJ, Frazer D, Shapiro RE, Castranova V, Billie M., Dedhia HV, 1997, Inhalation of toluene diisocyanate is associated with increased production of NO by rat bronchoalveolar lavage cells, Tox Appl Pharmacol, 145, 61-7.

9. Jovčić G, Stojanović N, Kataranovski M, Petakov M, Obradović $P, 1993$, Acute sterile inflammation correlation between cellular changes and extramedullary-produced regulators in vivo. Ann. Hematol. 66,195-201. 
10. Kim SH, Kim JS, Shin HS, Keen CL, 2003, Influence of smoking on markers of oxidative stress and serum mineral concentrations in teenage girls in Korea, Nutrition, 19, 240-3.

11. Mattia CJ, Adams JD, Bondy SC, 1993a, Free radical induction in the brain and liver by products of toluene catabolism, Bioch Pharmacol, 46, 103-10.

12. Mattia CJ, Ali SF, Bondy SC, 1993b, Toluene induced oxidative stress in several brain regions and other organs. Mol Chem Neuropathol, 18, 313-28.

13. Mazumder B, Mukhopadhyay CK, Prok A, Cathcart MK, Fox PL, 1997, Induction of ceruloplasmin synthesis by IFN gamma in human monocytic cells, $J$ Immunol, 159, 1938-44.

14. Milenković P, Ivanović Z, Lukić ML, Kataranovski M, Lord BI, 1993, Stimulator of proliferation of spleen colony-forming cells in acute sterile inflammation, Cell Prolif, 26, 503-10.

15. Moszczynski P, Starek A, 1980, Cytochemical and immunological studies in workers exposed to organic solvents of paints and varnishes. II. Metabolism of the neutrophils. Med Pr, 31, 7-11.

16. Moszczynski $P, 1983 a$, The effect of working environment contaminated with organic solvents on the activity of acid phosphatase in lymphocytes, Med In, 21, 37-42.

17. Moszczynski P, Lisiewicz J, 1983b, Effects of environment contaminated with benzene, toluene and xylene on acid phosphatase activity in lymphocytes, Folia Haem Int Mag Klin Morphol Blutforsch, 110, 948-54.

18. Myhre O, Fonnum F, 2001, The effect of aliphatic naphtenic and aromatic hydrocarbons on production of reactive oxygen species and reactive nitrogen species in rat brain synaptosome fraction: the involvment of calcium, nitric oxide synthase, mitochondria, and phospholipase A. Biochem Pharmacol, 62, 119-28.

19. Nedelcheva $V, 1996$, Effect of acetone on the capacity of o-xylene and toluene to induce several forms of cytochrome P450 in rat liver, Cent Eur J Public Health, 4, 119-22.

20. Neghab $M$, Stacey $N H$, 1997, Toluene -induced elevation of serum bile acids: relationship to bile acid transport. J Toxicol. Environ. Health, 52, 249-68.

21. Paguotto L.D, Liberman LM, 1967, Urinary hippuric acid excretion as an index of toluene exposure. Am Ind Hyg Assoc, 28, 129-34.

22. Patockova J, Marhol P, Tumova E, Krisiak M, Rokyta R, Stipek S et al. 2003, Oxidative stress in the brain tissue of laboratory mice with acute post insulin hypoglycemia. Physiol Res, 52,131-5.

23. Pedersen LM, Rasmussen JM, 1982, The haematological and biochemical pattern in occupational organic solvent poisoning and exposure, Int Arch Occup Environ Health, 51:113-26.

24. Reyes J, Holmgren J, 1991, Ceruloplasmin in patients with Duchenne muscular dystrophy: Ref Med Chil, 119, 258-61.

25. Saenko EL, Yaropolov AI, 1990, The protective effect of different forms of human ceruloplasmin in copper-induced lysis of red blood cells, Biochem Int, 22, 57-66.

26. Smith-Kielland A, Ripel A, 1993, Toluene metabolism in isolated rat hepatocytes: effects of in vivo pretreatment with acetone and phenobarbital, Arch Toxicol, 67, 107-12.

27. Stojanović Nevenka, Jovčić Gordana, P. Milenković, Biljanović-Paunović Lidija, Gotić Mirjana, 1988, Subletalno ozračeni miš kao eksperimentalni model za izučavanje hematopoeze in vivo. Billen Hematol Transf, 16, 43-52.

28. Sunderman FW, Nomoto S, 1970, Measurement of human serum ceruloplasmin by its pphenylenediamine oxidase activity,. Clin Chem, 16, 903-10.

29. Tamizhslevi R, Samikkannu T, Niranjali S, 1995, Pulmonary phospholipid changes induced by butylated hydroxytoluene, an antioxidant in rats. Indian J Exp Biol, 33, 796-7.

30. Tauler P, Agulio A, Cases N, Sureda A, Gimenez F, Villa G, Cordova A, Biescas AP, 2002, Acute phase immune response to exercise coexists with decreased neutrophil antioxidant enzyme defences. Free Radic Res, 36, 1101-7.

31. Tentori L, Salvati AM, 1981, Haemoglobinometry in human blood. Meth Enzymol, 76, 707-715.

32. Uchiyama M, Michara M, 1978, Determination of malondialdehyde precutrsors in tissue by thiobarbituric acid test. Anal Biochem, 86, 271-8.

33. Vassilakopoulos T, Karatza MH, Katsaounou P, Kollintza A, Zakynthinos S, Roussos C, 2003, Antioxidant attenuate the plasma cytokine response to exercise in humans, J Appl Physiol, 94, 102532. 
34. Wang RS, Nakajima T, Tsuruta H, Honma T, 1996, Effect of exposure to four organic solvents on hepatic cytochrome P450 isozyme in rats, Chem Biol Interact, 99, 239-52.

35. Yang F, Friedrich WE, deGraffenried L, Herbert DC, Weaker FJ, Bowman BH, Coalson JJ, 1996, Cellular expression of lung: anti-oxidant role, Am J Res Cell Mol Biol, 14, 161-9.

TOLUENOM POSREDOVANI OKSIDATIVNI STRES I GRANULO-MONOCITOPOEZA

BOŽIĆ TATJANA, STEVANOVIĆ JELKA, KOVAČEVIĆ MILICA, JOVIĆ S, LUKIĆ SANJA, PETAKOV MARIJANA, BOROZAN SUNČICA, MIJAČEVIĆ ZORA, KNEŽEVIĆ MILIJANA i BULAJIĆ SNEŽANA

\section{SADRŽAJ}

$\mathrm{U}$ ovom ogledu je ispitivan efekat toluena na biohemijske i hematološke parametre odraslih ženki Wistar pacova. Životinjama je intraperitonealno davan rastvor toluena u propilen glikolu, kao i propilen glikol, jednom dnevno u trajanju od 3, 7 i 11 dana. Efekti davanih rastvora odredjivani su biohemijskim i hematološkim ispitivanjima plazme, krvi i punktata kostne srži. U plazmi pacova određivani su koncentracije ukupnih proteina, albumina kao i koncentracija eritrocitnog malondialdehida (RBC MDA). Biohemijske promene manifestovale su se hipoalbuminemijom, porastom koncentracije ceruloplazmina i visokom koncentracijom RBC MDA. Ovi nalazi ukazuju na oštećenje endotela krvnih sudova praćeno odgovorom akutne faze. Promene u broju leukocita periferne krvi kao i povećanje broja granulocitno-monocitnih (CFU-GM) progenitora kostne srži takođe su ukazali na tipičan proinflamatorni odgovor.

Naši rezultati potvrđuju da toluen izaziva oksidativni stres i sterilni akutni peritonitis. Promene izazvane slobodnim radikalima kiseonika utiču i na odgovor progenitora kostne srži, pojavu koja do sada nije bila opisana. 